\title{
Pengaruh Upah Minimum, Kemiskinan dan Pengangguran pada IPM di Kabupaten/Kota Provinsi Jawa Timur
}

\section{The Influence of Minimum Wages, Poverty and Unemployment on HDI in Regency/City of East Java Province}

\author{
Moh. Faizin \\ Fakultas Ekonomi dan Bisnis Islam, Institut Agama Islam Negeri Ponorogo \\ e-mail korespondensi:faizin@iainponorogo.ac.id
}

\begin{tabular}{|l|}
\hline Info Artikel \\
\hline Riwayat Artikel : \\
Diterima: 01 Desember 2020 \\
Disetujui: 21 April 2021 \\
Dipublikasikan: Juli 2021 \\
\hline Nomor DOI \\
10.33059/jseb.v12i2.3027 \\
Cara Mensitasi : \\
Faizin, M. (2021). Pengaruh \\
upah minimum, kemiskinan \\
dan pengangguran pada IPM \\
di Kabupaten/Kota Provinsi \\
Jawa Timur. Jurnal Samudra \\
Ekonomi dan Bisnis, 12(2), \\
214-227. doi: 10.33059/jseb. \\
v12i2.3027.
\end{tabular}

v12i2.3027.

\begin{abstract}
Abstrak
Paradigma pembangunan suatu negara dewasa ini tidak hanya diukur dari laju pertumbuhan ekonominya, tetapi juga memperhatikan pembangunan manusia. Tujuan penelitian ini untuk menganalisis pengaruh upah minimum, kemiskinan dan pengangguran atas Indeks Pembangunan Manusia (IPM) pada kabupaten/ kota di Propinsi Jawa Timur. Metode yang digunakan adalah regresi data panel pada 38 kabupaten/kota di Jawa Timur tahun 2010/2018. Hasil penelitian menyatakan bahwa secara parsial, upah minimum memiliki pengaruh yang positif dan signifikan, kemiskinan memiliki pengaruh yang negatif namun tidak signifikan, dan pengangguran memiliki pengaruh yang negatif dan signifikan, terhadap IPM. Secara simultan, hasil penelitian menemukan ketiga variabel independen (yatu: upah minimum, kemiskinan dan pengangguran) mempunyai pengaruh yang signifikan terhadap IPM.
\end{abstract}

Kata Kunci: Upah Minimum, Kemiskinan, Pengangguran, IPM.

\begin{tabular}{|l|}
\hline Article Info \\
\hline Article History: \\
Received: 01 December 2020 \\
Accepted: 21 April 2021 \\
Published: July 2021
\end{tabular}

DOI Number :

10.33059/jseb.v12i2.3027

How to cite :

Faizin, M. (2021). Pengaruh upah minimum, kemiskinan dan pengangguran pada IPM di Kabupaten/Kota Provinsi Jawa Timur. Jurnal Samudra Ekonomi dan Bisnis, 12(2), 214-227. doi: 10.33059/jseb. v12i2.3027.

\section{Abstract}

The paradigm of development of a country today is not only measured by the rate of economic growth, but also by paying attention to human development. The purpose of this study was to analyze the effect of minimum wages, poverty and unemployment on the Human Development Index (HDI) in districts/cities in East Java Province. The method used is panel data regression in 38 districts/cities in East Java in 2010/2018. The results showed partially, the minimum wage has a positive and significant effect, poverty has a negative but not significant effect, and unemployment has a negative and significant effect, toward HDI. Simultaneously, the results found that the three independent variables (i.e.: minimum wage, poverty and unemployment) had a significant effect on HDI.

Keywords: Minimum Wage, Poverty, Unemployment, HDI. 


\section{PENDAHULUAN}

Perkembangan paradigma pembangunan bagi suatu negara tidak hanya diukur dari tingkat pertumbuhan ekonomi, tetapi juga dengan memperhatikan level pembangunan manusia termasuk didalamnya kualitas hidup manusia pada suatu daerah atau negara tersebut (Kahang et al., 2016). Selain itu, teori pembangunan cenderung banyak menekankan pada aspek akumulasi modal manusia dimana hal ini dilakukan melalui penciptaan generasi yang lebih produktif melalui peningkatan kualitas pengetahuan, perbaikan nutrisi dan kesehatan maupun peningkatan kualitas keterampilan. Perkembangan suatu negara dapat dinilai dengan menggunakan Indeks Pembangunan Manusia (IPM). Standar hidup, kesehatan serta pendidikan yang layak menjadi ukuran dalam menghitung tingkat IPM (Amalia et al., 2019). Sebuah negara dapat dikategorikan sebagai negara maju, berkembang ataupun dianggap negara yang tertinggal adalah dengan melihat seberapa tinggi nilai IPM di negara tersebut.

Kesejahteraan masyarakat tidak terlepas dari seberapa besar penghasilan yang mereka dapatkan. Upah bagi masyarakat merupakan sumber atas penghasilan. Apabila terjadi kenaikan atas jumlah penghasilan, tentunya akan berdampak pada kesejahteraan mereka. Sebaliknya, bila upah mengalami penurunan maka berdampak pada menaiknya tingkat kemiskinan (Ningrum, 2017). Kebijakan mengenai upah minimum kabupaten dan kota diharapkan nantinya dapat meningkatkan kesejahteraan masyarakat. Selain memberikan jaminan atas penghasilan atas pekerjaan kaum buruh, kebijakan upah minimum juga diharapkan mampu menjadi media distribusi pemerataan pembangunan pada tiap daerah. Peningkatan pendapatan masyarakat pada masing-masing daerah nantinya juga mampu mengurangi ketimpangan antar daerah dan berdampak pada berkurangnya laju migrasi penduduk desa ke kota (Marta et al., 2019). Kebijakan mengenai upah minimum juga pada ujungnya akan memberikan nilai tambah bagi peningkatan daya beli masyarakat.

Ketimpangan pendapatan di tengah masyarakat berdampak kepada terbentuknya jurang kemiskinan (Nisa et al., 2020). Kemiskinan itu sendiri merupakan persoalan pada setiap negara, dan seringkali menjadi permasalahan yang nyaris tidak ada ujungnya. Kemiskinan akan berakibat pada turunnya taraf hidup masyarakat sehingga berdampak pada terbatasnya pemenuhan kebutuhan setiap hari (Nasution, 2019). Ketidakberdayaan masyarakat dalam memenuhi kebutuhan dasar merupakan pengertian kemiskinan secara umum (Sartika et al., 2016). Pada sisi yang lain, kemiskinan menjadi pangkal persoalan sosial yang lain, baik masalah kriminalitas atan masalah ketidakmampuan masyarakat miskin untuk mendapatkan akses pendidikan dan kesehatan dan lapangan kerja secara layak. Hal ini tentu saja akan berdampak pada kesejahteraan masyarakat itu sendiri.

Ketidakmampuan akses pendidikan dan kesehatan dan lapangan kerja secara layak selanjutnya berdampak pada naiknya jumlah pengangguran pada angkatan kerja. Dengan kata lain, kemiskinan bisa berdampak pada pengangguran serta kurangnya pendapatan, dan selanjutnya pengangguran itu sendiri menjadikan terbentuknya masyarakat miskin. Perputaran siklus atas pengangguran dan kemiskinan tersebut apabila tidak dilakukan pemotongan mata rantai dengan kemudahan akses pendidikan dan kesehatan serta menciptakan lapangan pekerjaan maka akan terus menjadi siklus yang tidak pernah ada ujungnya. Kebijakan pemerintah pada bidang pendidikan dalam upaya mengentaskan kemiskinan tidak akan berdampak signifikan apabila tidak diimbangi dengan adanya kebijakan dalam bidang ketenagakerjaan (Nugraha, 2020). 
Jawa Timur sebagai salah satu provinsi strategis di Indonesia, khususnya di Pulau Jawa, dengan luas wilayah sebesar 47.800 $\mathrm{km}^{2}$ serta terdiri dari 38 kabupaten/kota dan jumlah penduduk sebanyak 39.699.000 jiwa. Data BPS menunjukkan Indeks Pembangunan Manusia (IPM) di Jawa Timur sebesar 70,77 dan upah rata-rata di kabupaten/kota sebesar Rp. 2,48 juta dimana yang tertinggi adalah Kota Surabaya sebesar Rp. 3,52 juta dan terendah adalah Kabupaten Situbondo sebesar Rp. 1,61 juta. Di sisi yang lain, angka kemiskinan dan pengangguran di provinsi tersebut terhitung masih relatif cukup tinggi, dimana data terakhir pada tahun 2020 menunjukkan angka kemiskinan sebesar 4.056.000 orang dan tingkat pengangguran terbuka sebesar 69,45 (BPS Provinsi Jawa Timur, 2020).

Penelitian terkait Indeks Pembangunan Manusia telah banyak dilakukan, tetapi menunjukkan hasil yang tidak konsisten. Penelitian yang dilakukan oleh Jasasila (2020) memperoleh bahwa derajat kemiskinan tidak memiliki pengaruh yang signifikan terhadap tingkat IPM. Hasil itu berbeda dibandingkan dari temuan-temuan penelitian milik Muliza et al. (2017), Tarumingkeng et al. (2018) serta Umiyati et al. (2017) yang menunjukkan bahwa kemiskinan memiliki pengaruh secara signifikan dan negatif terhadap level IPM.

Sementara pada kasus yang berbeda, hasil penelitian milik Meydiasari \& Soejoto (2017) menunjukkan bahwa pengangguran memiliki dampak yang negatif dan signifikan terhadap peningkatan IPM. Begitu pula dengan hasil empiris yang senada diperoleh sejumlah para ahli (Meydiasari \& Soejoto, 2017; Baeti, 2013; Hamzah et al., 2012; Ningrum et al., 2020; Arizal \& Marwan, 2019; Syofya, 2018) yang mengidentifikasi bahwa pengangguran mempunyai dampak negatif terhadap IPM.
Berbeda dengan riset-riset sebelumnya, penelitian ini menganalisis upah minimum, kemiskinan serta pengangguran sebagai variabel independen yang mempengaruhi level IPM. Berdasarkan latar belakang atau fenomena yang telah diuraikan, penelitian ini lebih jauh bertujuan menganalisis besaran pengaruh dari upah minimum, kemiskinan dan pengangguran terhadap IPM di wilayah kabupaten/kota Provinsi Jawa Timur.

\section{Indeks Pembangunan Manusia}

UNDP pertama kalinya menggunakan indikator IPM pada tahun 1990 (Heka, 2017). IPM diartikan oleh UNDP sebagai sebuah proses dalam memperluas berbagai pilihan pada penduduk berkaitan dengan pendapatan, kesehatan, pendidikan, lingkungan dan lain sebagainya. Pada setiap daerah sudah seharusnya menjadikan lingkup pembangunan manusia yang seutuhnya menjadi titik berat proses pembangunan. Hal ini bertujuan untuk meningkatkan kualitas hidup masyarakat secara fisik dan mental serta spiritual.

Manfaat yang dapat diperoleh dengan adanya penghitungan IPM diantaranya adalah peranan IPM sebagai parameter tingkat keberhasilan dalam membangun kualitas hidup yang ada di masyarakat. Pembangunan manusia yang tepat dan baik dapat meningkatkan level kesejahteraan masyarakat (Hatta \& Khoirudin, 2020). Selain itu, IPM dapat digunakan dalam menentukan peringkat suatu daerah/negara yang satu dengan daerah yang lain. Di sisi yang lain, IPM juga menjadi parameter atas kinerja sebuah pemerintahan dikarenakan peran pemerintah sebagai faktor fasilitator dan katalisator dalam proses pembangunan. Tingginya nilai IPM, dengan kata lain, menjadi cerminan atas semakin meningkatnya tingkat kesejahteraan penduduk (Ariza, 2016). 
Rata-rata pencapaian pembangunan suatu negara atau daerah dalam menggunakan IPM diukur berdasarkan tiga parameter, yaitu pendidikan, kesehatan dan ekonomi. Level kesehatan diukur dengan memperhatikan angka harapan hidup (AHY) saat kelahiran; tingkat pendidikan diukur dengan melihat rata-rata lama sekolah; serta, derajat ekonomi (hidup yang layak) dilihat menggunakan kemampuan daya beli atau PNB perkapita.

\section{Upah Minimum Kabupaten/Kota}

Pemberian upah minimal pada pekerja bertujuan agar para pekerja mendapatkan pengahsilan yang digunakan untuk memenuhi kebutuhan hidup yang layak. Upah minimum sendiri diartikan sebagai upah terendah yang diterima setiap bulan yang terdiri atas upah pokok dan tunjangan tetap dimana penetapan upah dilakukan gubernur. Masing-masing daerah mempunyai standar kebutuhan hidup yang berbeda, sehingga situasi ini yang menjadikan besaran upah minimum tidak berlaku secara nasional namun hanya berlaku untuk wilayah tertentu.

Menurut Peraturan Pemerintah Republik Indonesia Nomor 78 Tahun 2015 tentang Pengupahan, upah minimum terbagi atas: (a) upah minimum provinsi; (b) upah minimum kabupaten/kota; (c) upah minimum sektoral provinsi; dan, (d) upah minimum sektoral kabupaten/kota. Penetapan upah dilakukan oleh gubernur selaku kepala daerah. Penetapan upah minimum disesuaikan dengan penilaian kebutuhan hidup layak serta dengan memperhatikan produktivitas dan pertumbuhan ekonomi. KHL merupakan standar kebutuhan seorang pekerja yang masih lajang untuk dapat hidup layak selama satu bulan.

Berbeda dengan sejumlah riset empiris terdahulu, penelitian ini menyoroti upah minimum sebagai variabel yang dinilai mempengaruhi IPM. Hal ini didasarkan pada fakta bahwa kebijakan penetapan upah minimum merupakan bagian dari instrumen kebijakan dalam penciptaan pemerataan hasil pembangunan sebagai upaya mengurangi ketimpangan antar daerah. Melalui penerapan kebijakan upah minimum secara tepat diharapkan akan mengurangi laju migrasi dari desa ke kota. Pada saat yang sama, kebijakan upah minimum juga dapat berdampak pada naiknya Indeks Pembangunan Manusia di daerah yang bersangkutan. Berdasarkan pemikiran itu, maka hipotesis pertama yang dimunculkan untuk dianalisis pada penelitian ini bahwa upah minimum berpengaruh secara positif dan signifikan terhadap IPM.

\section{Kemiskinan}

Kemiskinan didefinisikan sebagai level ketidakmampuan seseorang dalam memenuhi kebutuhan standar. Kemiskinan digolongkan menjadi beberapa bagian. Golongan pertama adalah kemiskinan absolut, yakni kemiskinan yang dialami seseorang karena pendapatan rendah dan tidak dapat memenuhi kebutuhan hidupnya. Golongan kedua yaitu kemiskinan relatif, atau derajat kemiskinan yang dialami seseorang dengan kondisi di atas garis kemiskinan tetapi berada pada jarak antara miskin dan non miskin. Golongan ketiga adalah kemiskinan struktural, yakni level kemiskinan yang diderita oleh seseorang yang mengalami kemiskinan tetapi mereka lebih bersikap enggan untuk melakukan perbaikan hidupnya hingga ada bantuan untuk dapat keluar keadaan tersebut.

Dewasa ini definisi kemiskinan menjadi lebih komplek, dimana dimensi kemiskinan mencakup permasalahan adanya kerentanan, ketidakberdayaan serta ketidakmampuan dalam menyampaikan informasi. Hal ini menjadikan kemiskinan menjadi lebih multidimensi dalam masyarkat. Kemiskinan juga dianggap sebagai ketidaksamaan kesempatan dalam mengakumulasikan kekuatan sosial 
baik berupa modal dan asset, jaringan sosial dalam memperoleh pekerjaan, barang dan jasa. Ketidakmampuan dalam mendapatkan pengetahuan dan keterampilan serta informasi yang bermanfaat dalam kemajuan hidup mereka juga dapat dinilai sebagai kemiskinan (Palenewen et al., 2018).

Penelitian-penelitian terdahulu terkait variabel kemiskinan terhadap IPM yang telah dilakukan menunjukkan hasil yang tidak konsisten. Penelitian Jasasila (2020) menemukan hasil bahwa kemiskinan tidak memiliki pengaruh secara signifikan terhadap tingkat IPM. Sebaliknya, studi-studi yang dilakukan oleh Muliza et al. (2017), Tarumingkeng et al. (2019) serta Umiyati et al. (2017) secara empiris memperoleh kemiskinan berpengaruh secara negatif dan signifikan terhadap IPM. Adanya gap riset itu mendasari dirumuskannya hipotesis kedua pada penelitian ini yaitu bahwa kemiskinan memiliki pengaruh yang negatif dan signifikan terhadap IPM.

\section{Pengangguran}

Pengangguran didefinisikan sebagai kondisi seseorang yang sudah termasuk dalam angkatan kerja dan yang secara aktif sedang mencari pekerjaan untuk tingkat upah tertentu, tetapi orang itu tidak mendapatkan pekerjaan yang ia inginkan. Lebih jauh, pengangguran terbuka adalah bagian dari angkatan kerja yang belum bekerja dan sedang mencari pekerjaan (Sukirno, 2004).

Penelitian terdahulu berkaitan dengan pengaruh pengangguran terhadap IPM seperti milik Meydiasari \& Soejoto (2017), Baeti (2013) serta Hamzah et al. (2012) menemukan hasil empiris yang menunjukkan bahwa pengangguran mempunyai dampak negatif dan signifikan terhadap peningkatan IPM. Temuan-temuan serupa bahwa pengangguran memiliki dampak negatif terhadap IPM juga diperoleh Ningrum et al. (2020), Arizal \& Marwan (2019) maupun Syofya (2018).
Berdasarkan sejumlah hasil empiris tersebut maka dirumuskan hipotesis ketiga pada penelitian ini yaitu bahwa pengangguran berpengaruh negatif dan signifikan terhadap nilai IPM.

\section{METODE PENELITIAN}

Penelitian ini menggunakan analisis regresi data panel yang merupakan perpaduan data time series (runtut waktu) serta data cross section. Tujuan dari metode analisis estimasi adalah memperkirakan parameter regresi yang berupa intersep dan slope (Sakti, 2018; Sriyana, 2015). Penggunaan analisis regresi data panel dalam penelitian ini dinilai menjadi pilihan yang tepat, karena data terdiri dari banyak obyek pengamatan (kabupaten/ kota) serta terdiri dari beberapa periode waktu tertentu.

Data panel yang digunakan bersumber pada masing-masing kabupaten/kota yang ada di Jawa Timur yang total berjumlah 38 kabupaten dan kota. Sumber data berasal dari BPS untuk periode tahun 2010 sampai dengan 2018. Data sekunder yang digunakan adalah data Upah Minimum Kabupaten/kota (UMK), persentase kemiskinan, data pengangguran yang digunakan sebagai variabel independen, serta data Indeks Pembangunan Manusia (IPM) sebagai variabel dependen. Persamaan data panel pada penelitian ini adalah:

$$
\begin{aligned}
\text { IPM }_{i t}= & \alpha+\beta_{1} \text { Upah Minimum }_{i t}+\beta_{2} \text { Kemiskinan }_{i t} \\
& +\beta_{3} \text { Pengangguran }_{i t}+\varepsilon_{i t}
\end{aligned}
$$

Tahapan-tahapan yang diperlukan dalam analisis regresi data panel adalah melakukan pemilihan model, menjalankan uji asumsi klasik, serta melakukan interpretasi model.

\section{Pemilihan Model}

Estimasi model data panel bertujuan untuk menentukan estimasi terbaik suatu model. Dalam mengestimasi model terdapat tiga model (Baltagi, 2008; Croissant \& Millo, 
2008). Pertama yaitu model CEM (Common Effect Model) yang merupakan model data panel yang paling sederhana karena hanya sekedar menggabungkan data cross section dan time series tanpa perlu memperhatikan perbedaan waktu dan obyek. Kedua adalah model FEM (Fixed Effect Model) yang menggunakan variabel dummy untuk menangkap adanya perbedaan pada intersep serta berasumsi bahwa slop antar obyek dan antar waktu bersifat tetap. Ketiga yaitu model REM (Random Effect Model) yang melakukan estimasi dimana variabel penganggu di anggap saling berpengaruh antar obyek dan antar waktu.

Terdapat tiga jenis pengujian atas estimasi data panel pada model CEM, FEM dan model REM untuk memilih model yang tepat, yaitu: (1) Uji Chow yang digunakan untuk memilih antara model CEM dan model FEM; (2) Uji Hausman yang bertujuan untuk menentukan model yang paling tepat antara model FEM dan model REM; serta, (3) Uji Lagrange Multiplier yang bertujuan untuk memilih model paling tepat antara model REM dan model CEM (Basuki \& Prawoto, 2016).

\section{Uji Asumsi Klasik}

Tahap selanjutnya yakni melakukan uji asumsi klasik, meliputi uji normalitas, uji multikolinieritas, dan uji heteroskedastisitas.

Uji normalitas berguna untuk melihat normal dan tidaknya distribusi data yang digunakan. Uji ini diperlukan karena apabila residual tidak terdistribusi secara normal maka akan berakibat pada penggunaan uji $t$ dalam melihat koefisien regresi menjadi tidak relevan (Gujarati, 2016). Uji normalitas dalam penelitian ini menggunakan uji Jarque-Bera, dimana dalam mengambil keputusan atas hasil uji didasarkan pada nilai probabilitas yang dibandingkan dengan nilai signifikansi ( $\alpha$ ) sebesar 0,05 (Widarjono, 2013). Kriteria penilaian adalah apabila probabilitas JarqueBera lebih besar dari $\alpha$ maka dinyatakan residual mempunyai distribusi normal; namun, jika probabilitas Jarque-Bera lebih kecil dari $\alpha$ maka dinyatakan residual tidak mempunyai distribusi normal.

Uji multikolinieritas dilakukan apabila model pada regresi memiliki variabel bebas jamak (lebih dari satu), yaitu untuk melihat ada atau tidaknya hubungan secara linier pada masing-masing variabel bebas (Gujarati, 2016). Apabila terjadi multikolinearitas, dampaknya adalah banyak dari variabel independen bisa menjadi tidak signifikan sementara koefisien determinasi memilikii nilai tinggi dalam mempengaruhi variabel dependen (Basuki \& Prawoto, 2016). Kriteria penilaian yaitu jika nilai korelasi dari setiap variabel independen lebih kecil dari 0,8 maka dinyatakan data semua variabel tidak mengalami multikolinieritas.

Uji Heteroskedastisitas dilakukan untuk menggambarkan nilai dari residual pada model memiliki varians yang konstan atau tidak. Pengujian ini menjadi penting karena apabila pada model terjadi heteroskedastisitas maka hasil uji $t$ dan uji $F$ tidak bisa akurat (Widarjono, 2013; Gujarati, 2016). Kriteria penilaian dari uji heteroskedastisitas adalah jika nilai probabilitas (prob.) dari semua variabel bebas lebih besar dari $\alpha(0,05)$ maka dapat dinyatakan bahwa tidak terjadi heteroskedastisitas di dalam model regresi.

\section{Interpretasi Model}

Tahap terakhir dalam model regresi data panel adalah dengan melakukan interpretasi model. Interpretasi model dilakukan dengan melihat koefisien pada masing-masing variabel independen (Basuki \& Prawoto, 2016; Sriyana, 2015). Dalam menginterpretasikan terdapat dua hal yang perlu untuk diperhatikan, yaitu: (1) besar kecilnya nilai koefisien; dan, (2) tanda positif atau 
negatif pada nilai koefisien tersebut. Nilai koefisien menjelaskan besarnya pengaruh variabel independen atas variabel dependen; sementara tanda positif ataupun negatif menunjukkan apakah hubungan antar variabel berlangsung secara berbanding lurus atau berbanding terbalik.

Pada tahap ini, sama halnya dengan model regresi linier berganda, juga dilakukan uji hipotesis pada analisis regresi data panel menggunakan uji $t$ dan uji $F$. Uji t digunakan untuk menganalisis aapakah pengaruh variabel independen secara parsial terhadap variabel dependen bersifat signifikan atau tidak, dengan kriteria penilaian jika nilai probabilitas dari suatu variabel independen lebih kecil dari $\alpha(0,05)$ maka dinyatakan bahwa variabel independen tersebut secara parsial memiliki pengaruh yang signifikan terhadap variabel dependen (Gujarati, 2016; Widarjono, 2013). Sementara itu, uji F digunakan untuk melihat pengaruh secara simultan dari semua variabel independen dalam mempengaruhi variabel dependen, dengan kriteria penilaian yaitu jika nilai probabilitas yang diperoleh keseluruhan variabel independen lebih kecil dari $\alpha(0,05)$ maka dinyatakan semua variabel independen secara simultan memiliki pengaruh signifikan atas variabel dependen (Basuki \& Prawoto, 2016; Gujarati, 2016).

Pada tahap ini juga dianalisis nilai koefisien determinasi $\left(\mathrm{R}^{2}\right)$ yang berfungsi mengidentifikasi besaran kemampuan ketiga variabel independen (yaitu: upah minimum. Kemiskinan dan pengangguran) yang dibahas dalam penelitian ini untuk menjelaskan variasi naik turunnya derajat IPM. Model dikatakan baik apabila nilai $\mathrm{R}^{2}$ mendekati angka 1; namun sebaliknya, semakin kecil nilai $\mathrm{R}^{2}$ dan mendekati angka 0 maka model dikatakan kurang baik (Gujarati, 2016).

\section{HASIL ANALISIS \\ Hasil Pemilihan Model}

Langkah pertama dalam analisis regresi data panel melakukan estimasi atas tiga model, yaitu CEM (Common Effect Model), FEM (Fixed Effect Model), dan REM (Random Effect Model), sehingga bisa dilakukan pemilihan model yang paling tepat bagi proses analisis penelitian ini. Tabel 1 memuat hasil estimasi pemilihan model. Pada Tabel 1 diperoleh bahwa hasil estimasi untuk masing-masing model CEM, FEM dan REM, mempunyai nilai signifikansi yang berbeda.

Tahap selanjutnya adalah melakukan pemilihan model yang paling tepat. Untuk pemilihan tahap pertama, yakni pemilihan antara model CEM dengan model FEM, digunakan Uji Chow. Hasil uji Chow pada Tabel 1 menunjukkan bahwa nilai Crosssection Chi-square yang diperoleh adalah sebesar 0,000 atau lebih kecil dari $\alpha(0,05)$. Dengan demikian dinyatakan pemilihan model yang dianggap paling tepat adalah model FEM.

Pengujian kedua dijalankan dengan menggunakan uji Hausman, yaitu dalam menentukan model yang dianggap paling tepat antara model FEM dan model REM. Hasil dalam Tabel 1 menunjukkan nilai probabilitas dari uji Hausman adalah sebesar 0,000 atau lebih kecil dari $\alpha(0,05)$. Hasil ini menunjukkan model paling tepat berdasarkan hasil uji Hausman adalah model FEM.

Dalam pemilihan model pada regresi data panel seharusnya dilakukan sebanyak tiga tahapan, yakni uji Chow, uji Hausman dan uji Lagrange Multiplier. Tetapi karena pada tahapan uji Chow dan uji Hausman telah menunjukkan bahwa pemilihan model yang tepat adalah model FEM, maka uji Lagrange Multiplier tidak perlu dilakukan lagi. 
Tabel 1. Hasil Estimasi dan Pemilihan Model

\begin{tabular}{|c|c|c|c|c|c|c|}
\hline \multirow{2}{*}{ Variabel } & \multicolumn{2}{|c|}{ Common Effect } & \multicolumn{2}{|c|}{ Fixed Effect } & \multicolumn{2}{|c|}{ Random Effect } \\
\hline & $t$-Statistic & Prob. & $t$-Statistic & Prob. & t-Statistic & Prob. \\
\hline Upah minimum & 6,982617 & 0,0000 & 25,78358 & 0,0000 & 25,38463 & 0,0000 \\
\hline Kemiskinan & 7,085384 & 0,0000 & $-1,753223$ & 0,0806 & $-0,903731$ & 0,3668 \\
\hline Pengangguran & $-18,79452$ & 0,0000 & $-8,043941$ & 0,0000 & $-10,41204$ & 0,0000 \\
\hline \multicolumn{7}{|l|}{ Pemilihan Model } \\
\hline \multirow[t]{3}{*}{ Uji Chow } & \multicolumn{3}{|l|}{ Effects Test } & Statistic & d.f. & Prob. \\
\hline & \multicolumn{3}{|c|}{ Cross-section $F$} & 110,644367 & $(37.301)$ & 0,0000 \\
\hline & \multicolumn{3}{|c|}{ Cross-section Chi-square } & 916,928163 & 37 & 0,0000 \\
\hline \multirow[t]{2}{*}{ Uji Hausman } & \multicolumn{2}{|c|}{ Test Summary } & & $\begin{array}{l}\text { Chi-Sq. } \\
\text { Statistic }\end{array}$ & $\begin{array}{c}\text { Chi-Sq. } \\
\text { d.f. }\end{array}$ & Prob. \\
\hline & \multicolumn{3}{|c|}{ Cross-section random } & 49,593060 & 3 & 0,0000 \\
\hline
\end{tabular}

Sumber: Data diolah, 2020.

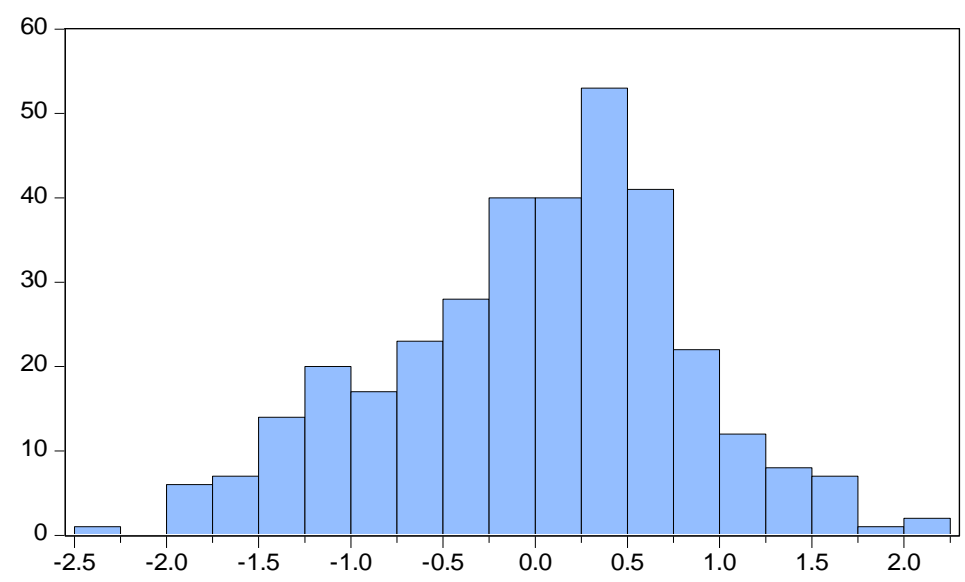

\begin{tabular}{|lc|}
\hline \multicolumn{2}{|l|}{ Series: Standardized Residuals } \\
Sample 2010 2018 \\
Observations & 342 \\
& \\
Mean & $2.47 \mathrm{e}-17$ \\
Median & 0.086497 \\
Maximum & 2.077745 \\
Minimum & -2.325901 \\
Std. Dev. & 0.804997 \\
Skewness & -0.250493 \\
Kurtosis & 2.779979 \\
& \\
Jarque-Bera & 4.266395 \\
Probability & 0.118458 \\
\hline
\end{tabular}

Gambar 1. Hasil Uji Normalitas

Sumber: Data diolah, 2020.

\section{Hasil Uji Asumsi Klasik}

Uji asumsi klasik pertama yang dilakukan yaitu uji normalitas, dengan menggunakan uji Jaque-Bera. Berdasarkan hasil uji normalitas sebagaimana dapat dilihat pada Gambar 1, diketahui bahwa nilai probabilitas sebesar 0,118. Karena nilai probabilitas tersebut lebih besar dibandingkan dengan nilai signifikansi $(\alpha)$ sebesar 0,05 maka dinyatakan bahwa residual di dalam model penelitian ini adalah terdistribusi secara normal.

Uji asumsi klasik kedua adalah uji multikolinieritas, yang dijalankan dengan tujuan untuk mengetahui ada atau tidaknya varians yang konstan dari terbentuknya model. Berdasarkan hasil uji multikolinieritas pada Tabel 2 diperoleh nilai korelasi dari masing-masing variabel bebas lebih kecil dari 0,80 . Dengan demikian dapat dinyatakan bahwa data dari semua variabel yang dianalisis dalam penelitian ini tidak terjadi multikolinieritas.

Uji asumsi klasik ketiga adalah uji heteroskedastisitas, dimana hasil olah data yang diperoleh dirangkum dalam Tabel 3. Tabel tersebut menunjukkan bahwa nilai probabilitas dari kesemua variabel bebas yaitu lebih besar dibandingkan $\alpha(0,05)$. Hasil ini menyatakan tidak terjadi heteroskedastisitas 
dalam model penelitian ini, atau bahwa tidak terdapat penyimpangan asumsi klasik yang terjadi pada model, sehingga dapat dilakukan analisis data panel tahap berikutnya.

\section{Hasil Interpretasi Model}

Dalam tahap uji pemilihan model, telah diperoleh hasil uji Chow dan uji Hausman bahwa model yang dianggap paling tepat dalam bahasan penelitian ini adalah model FEM (Fixed Effect Model). Karenanya pada tahap interpretasi model dilakukan proses estimasi model menggunakan FEM.

Berdasarkan hasil estimasi model FEM yang dirangkum dalam Tabel 4, dengan memperhatikan nilai koefisien dari masingmasing variabel, maka didapatkan persamaan model bagi penelitian ini sebagai berikut:

$I P M=67,852+2,82$ Upah Minimum - 0,085 Kemiskinan-0,235 Pengangguran

Tabel 2. Hasil Uji Multikolinieritas

\begin{tabular}{cccc}
\hline & Upah minimum & Kemiskinan & Pengangguran \\
\hline Upah minimum & 1,000000 & 0,159171 & $-0,301175$ \\
Kemiskinan & 0,159171 & 1,000000 & $-0,396720$ \\
Pengangguran & $-0,301175$ & $-0,396720$ & 1,000000 \\
\hline
\end{tabular}

Sumber: Data diolah, 2020.

Tabel 3. Hasil Uji Heteroskedastisitas

\begin{tabular}{crrrr}
\hline Variable & \multicolumn{1}{c}{ Coefficient } & \multicolumn{1}{c}{ Std. Error } & \multicolumn{1}{c}{ t-Statistic } & \multicolumn{1}{c}{ Prob. } \\
\hline C & 0.552504 & 0.142875 & 3.867038 & 0.0001 \\
Upah minimum & $5.47 \mathrm{E}-08$ & $4.55 \mathrm{E}-08$ & 1.203498 & 0.2296 \\
Kemiskinan & -0.001215 & 0.018005 & -0.067472 & 0.9462 \\
Pengangguran & 0.001663 & 0.005428 & 0.306345 & 0.7595 \\
\hline
\end{tabular}

Sumber: Data diolah, 2020.

Tabel 4. Hasil Fixed Effect Model (FEM)

\begin{tabular}{|c|c|c|c|c|}
\hline Variable & Coefficient & Std. Error & $t$-Statistic & Prob. \\
\hline $\mathrm{C}$ & 67,85210 & 0,503509 & 134,7586 & 0,0000 \\
\hline Upah minimum & $2,82 \mathrm{E}-06$ & $1,09 \mathrm{E}-07$ & 25,78358 & 0,0000 \\
\hline Kemiskinan & $-0,085576$ & 0,048811 & $-1,753223$ & 0,0806 \\
\hline Pengangguran & $-0,235821$ & 0,029317 & $-8,043941$ & 0,0000 \\
\hline \multicolumn{5}{|c|}{ Effects Specification } \\
\hline \multicolumn{5}{|c|}{ Cross-section fixed (dummy variables) } \\
\hline$R$-squared & 0,979756 & \multicolumn{2}{|c|}{ Mean dependent var } & 68,37269 \\
\hline Adjusted R-squared & 0,977066 & \multicolumn{2}{|c|}{ S.D. dependent var } & 5,657790 \\
\hline S.E. of regression & 0,856817 & \multicolumn{2}{|c|}{ Akaike info criterion } & 2,640882 \\
\hline Sum squared resid & 220,9749 & \multicolumn{2}{|c|}{ Schwarz criterion } & 3,100610 \\
\hline Log likelihood & $-410,5908$ & \multicolumn{2}{|c|}{ Hannan-Quinn criter. } & 2,824025 \\
\hline$F$-statistic & 364,1912 & \multicolumn{2}{|c|}{ Durbin-Watson stat } & 0,440020 \\
\hline $\operatorname{Prob}(F$-statistic $)$ & 0,000000 & & & \\
\hline
\end{tabular}

Sumber: Data diolah, 2020. 
Interpretasi atas model atau persamaan regresi tersebut adalah sebagai berikut. Nilai konstanta menyatakan bahwa nilai IPM adalah sebesar 67,862 jika ketiga variabel independen (upah minimum, kemiskinan dan pengangguran) tidak mengalami perubahan nilai atau bersifat konstan. Selanjutnya, diperoleh koefisien regresi dari variabel upah minimum bernilai positif yang diinterpretasikan bahwa arah pengaruh dari variabel independen ini bersifat searah terhadap variabel dependen. Atau, bahwa jika besaran upah minimum yang diberikan kepada pekerja mengalami kenaikan maka nilai IPM juga akan mengalami kenaikan; sebaliknya, jika besaran upah minimum yang diperoleh pekerja mengalami penurunan maka nilai IPM akan mengalami penurunan pula.

Kondisi yang berbeda teridentifikasi berdasarkan model regresi dari penelitian ini dimana diperoleh koefisien regresi baik dari variabel kemiskinan maupun variabel pengangguran adalah bernilai negatif, yang diinterpretasikan bahwa arah pengaruh dari kedua variabel independen ini bersifat berlawanan terhadap variabel dependen. Dengan demikian, bahwa jika tingkat kemiskinan atau derajat pengangguran suatu daerah mengalami kenaikan maka akan menyebabkan nilai IPM yang dicapai daerah tersebut mengalami penurunan; sebaliknya, jika tingkat kemiskinan ataupun derajat pengangguran yang dialami suatu daerah mengalami penurunan maka nilai IPM yang dicapai daerah itu akan mengalami kenaikan.

Lebih jauh, berdasarkan Tabel 4, dapat diidentifikasi apakah pengaruh dari variabelvariabel independen terhadap variabel dependen bersifat signifikan atau tidak signifikan. Hasil uji hipotesis secara parsial (uji t) atas upah minimum menyatakan bahwa variabel independen tersebut memiliki pengaruh yang signifikan terhadap IPM, karena nilai probabilitas yang diperoleh lebih kecil dari $\alpha(0,000<0,05)$. Dengan demikian, hasil analisis ini menyatakan hipotesis pertama yang dimunculkan dalam penelitian ini yaitu bahwa upah minimum yang berlaku di suatu daerah berpengaruh secara positif dan signifikan terhadap nilai IPM pada daerah tersebut dapat dibuktikan secara empiris.

Berikutnya, hasil uji hipotesis secara parsial (uji t) atas kemiskinan menyatakan bahwa variabel independen ini memiliki pengaruh yang bersifat tidak signifikan terhadap IPM, karena nilai probabilitas yang diperoleh lebih besar dari $\alpha(0,0806>0,05)$. Dengan demikian, hasil analisis ini menolak secara empiris atas hipotesis kedua yang dimunculkan dalam penelitian ini karena hasil yang teridentifikasi menyatakan bahwa tingkat kemiskinan yang dialami suatu daerah berpengaruh secara negatif namun tidak signifikan atas capaian IPM pada daerah itu.

Hasil uji hipotesis secara parsial (uji t) mengenai pengangguran menyatakan variabel independen tersebut memiliki pengaruh yang signifikan terhadap IPM, karena nilai probabilitas yang diperoleh lebih kecil dari $\alpha$ $(0,000<0,05)$. Hasil analisis ini karenanya membuktikan hipotesis ketiga yang dimunculkan dalam penelitian ini secara empiris, yaitu bahwa derajat pengangguran yang dialami suatu daerah berpengaruh secara negatif dan signifikan terhadap nilai IPM yang dicapai oleh daerah yang bersangkutan.

Terakhir, hasil uji hipotesis secara simultan (uji F) yang terangkum dalam Tabel 4 menunjukkan pengaruh dari ketiga variabel independen secara keseluruhan memiliki sifat signifikan atas IPM, karena nilai probabilitas F yang diperoleh lebih kecil dari $\alpha(0,000<$ 0,05). Sebagai tambahan, berdasarkan Tabel 4 jugam diperoleh nilai Adjusted $R^{2}$ sebesar 0,9771 yang menyatakan intrepretasi bahwa kemampuan dari ketiga variabel independen yang dianalisis pada penelitian ini dalam menjelaskan varians yang terjadi atas capaian 
nilai IPM adalah sebesar 97,71\%; selebihnya sebesar 2,29\% menyatakan bahwa fluktuasi nilai IPM juga dipengaruhi oleh variabelvariabel yang lain tidak dianalisis dalam model penelitian ini.

\section{Pembahasan}

Hasil analisis menyatakan bahwa upah minimum memiliki pengaruh secara positif dan signifikan terhadap peningkatan IPM. Hal ini berarti kenaikan kebijakan pemerintah dalam menaikkan upah minimum akan mempunyai dampak positif pada peningkatan pendapatan dalam masyarakat (Pemerintah Indonesia, 2015). Dampak dari kenaikan pendapatan yang ada di masyarakat tersebut akan berdampak pula pada kemudahan akses dari sisi pendidikan, kesehatan serta perekonomian yang dilakukan masyarakat (Ningrum, 2017; Marta, 2019). Dengan demikian, penelitian ini telah membuktikan secara empiris bahwa kenaikan atas upah minimum dapat berdampak kepada kenaikan kualitas hidup masyarakat yang berujung pada kenaikan nilai IPM pada daerah atau wilayah tersebut.

Faktor kemiskinan berdasarkan hasil penelitian ini terbukti memiliki arah pengaruh yang negatif namun tidak signifikan terhadap IPM. Hasil penelitian ini membuktikan bahwa tingkat kemiskinan berpengaruh terhadap kualitas hidup manusia itu sendiri, namun pengaruh itu tidak bersifat nyata atau secara langsung. Hasil dari penelitian ini mendukung temuan yang diperoleh Jasasila (2020) bahwa kemiskinan tidak memiliki pengaruh secara signifikan terhadap IPM. Di sisi lain, hasil penelitian ini menentang argumen empiris milik Ningrum et al. (2020) yang menyatakan kemiskinan berpengaruh secara signifikan terhadap IPM. Begitu pula, hasil penelitian ini tidak mendukung temuan-temuan empiris terdahulu milik Arizal \& Marwan (2019), Sinuraya (2020), Tarumingkeng et al. (2019) serta Umiyati et al. (2017) yang memperoleh bahwa kemiskinan berpengaruh secara negatif dan signifikan terhadap IPM. Dengan demikian, hasil ini secara empiris mengidentifikasi bahwa semakin tinggi angka kemiskinan pada suatu suatu wilayah maka akan berdampak pada semakin rendahnya tingkat IPM di wilayah tersebut; akan tetapi pengaruh yang dittimbulkan oleh tingkat kemiskinan tersebut bersifat tidak langsung atas IPM. Karenanya, dibutuhkan bentukbentuk instrumen kebijakan pemerintah lainnya yang berfungsi sebagai pendukung upaya mengurangi serta menurunkan level angka kemiskinan yang mutlak dibutuhkan.

Selanjutnya, penelitian ini memperoleh temuan hasil bahwa tingkat pengangguran mempunyai pengaruh yang signifikan atas IPM. Nilai koefisien dalam persamaan regresi yang didapat menunjukkan tanda negatif, dimana mengandung arti bahwa terdapat hubungan yang terbalik antara pengangguran terhadap IPM; atau bahwa setiap terjadi peningkatan terhadap angka pengangguran maka akan berdampak pada penurunan angka indeks pembangunan manusia (IPM). Hasil penelitian ini memperluas temuan empiris terdahulu milik Meydiasari \& Soejoto (2017), Baeti (2013), Hamzah et al. (2012), Ningrum et al. (2020), Arizal \& Marwan (2019), Sinuraya (2020), serta Syofya (2018).

Hasil penelitian ini lebih jauh memberi penjelasan bahwa tingkat pengangguran pada tiap-tiap daerah pengangguran seharusnya diturunkan dalam upaya meningkatkan level kualitas hidup dari masyarakat. Kebijakan mengurangi angka pengangguran dapat dilakukan oleh pemerintah daerah dengan membuka lapangan pekerjaan, melaksanakan program pembangunan padat karya, serta mempermudah iklim investasi di daerah; dan di sisi lain, diperlukan juga peningkatan kualitas keterampilan yang terdapat di dalam masyarakat di daerah yang bersangkutan. 
Temuan akhir dalam penelitian ini menunjukkan bahwa baik upah minimum, kemiskinan maupun pengangguran secara simultan atau bersama-sama memberikan pengaruh yang signifikan terhadap tingkat IPM. Hasil ini menjelaskan bahwa pihak pemerintah daerah secara khusus dapat menjalankan strategi peningkatan IPM di daerahnya melalui penekanan pada ketiga faktor tersebut. Argumen ini didukung oleh temuan koefisien determinasi pada penelitian ini bahwa ketiga faktor tersebut memiliki kontribusi sangat besar dalam mempengaruhi derajat variabilitas pergerakan nilai IPM.

\section{SIMPULAN}

Hasil-hasil penelitian ini menyimpulkan bahwa secara simultan, baik upah minimum, kemiskinan maupun pengangguran, memiliki pengaruh yang signifikan terhadap IPM. Namun secara parsial, upah minimum memiliki pengaruh yang bersifat positif (searah) dan signifikan, kemiskinan memiliki pengaruh yang negatif (berlawanan) tetapi tidak signifikan, dan pengangguran memiliki pengaruh yang negatif (berlawanan) dan signifikan, terhadap IPM.

Hasil penelitian ini diekspektasikan bisa digunakan sebagai bahan rujukan dalam menentukan kebijakan pemerintah daerah dalam mengatasi persoalan ekonomi sosial kemasyarakatan di setiap daerah. Kebijakan masing-masing daerah dalam permasalahan perekonomian tidak seharusnya berorientasi masih kepada kebijakan meningkatkan angka pertumbuhan ekonomi secara makro saja, tetapi juga diperlukan kebijakan yang dapat langsung menyentuh dan dapat dirasakan oleh masyarakat secara langsung. Di antara bentuk kebijakan itu tentunya dengan menerapkan kebijakan yang tepat terkait penetapan upah minimum, penurunan angka kemiskinan dan angka pengangguran. Dengan penerapan bentuk kebijakan yang tepat tersebut nantinya akan berdampak kepada peningkatan kualitas pembangunan manusia (IPM) di daerah atau wilayah yang bersangkutan.

Rekomendasi yang diberikan untuk penelitian berikutnya adalah diharapkan menggunakan model pendekatan melalui variabel-variabel independen yang berbeda, penggunaan metode analisis data yang bervariasi, serta periode penelitian yang lebih panjang. Dengan usaha ini dinilai akan memberikan temuan empiris yang lebih akurat, lebih 'kaya', serta mendalam atas kondisi riil yang berlaku.

\section{REFERENSI}

Amalia, R. Y., Fauziah, S., \& Wahyuningsih, I. (2019). Pengaruh keuangan syariah terhadap pertumbuhan ekonomi dan indeks pembangunan manusia di Indonesia. Al-Muzara'ah, 7(1), 33-46. doi: 10.29244/jam.7.1.33-46.

Ariza, A. (2016). Pengaruh pertumbuhan ekonomi dan belanja modal terhadap indeks pembangunan manusia (IPM) dalam perspektif Islam. Al-Maslahah Jurnal Ilmu Syariah, 12(1), 1-21. doi: 10.24260/almaslahah.v12i1.348.

Arizal, M., \& Marwan, M. (2019). Pengaruh produk domestik regional bruto dan indeks pembangunan manusia terhadap tingkat pengangguran terbuka di Provinsi Sumatera Barat. Jurnal Ecogen, 2(3), 433. doi: 10.24036/jmpe. v2i3.7414.

Baeti, N. (2013). Pengaruh pengangguran, pertumbuhan ekonomi, dan pengeluaran pemerintah terhadap pembangunan manusia kabupaten/kota di Provinsi Jawa Tengah tahun 20072011. Economics Development Analysis Journal, 2(3), 85-98. doi: 10.15294/ edaj.v2i3.1984.

Baltagi, B. H. (2013). Econometrics analysis of panel data (5th ed). Wiley.

Basuki, A. T., \& Prawoto, N. (2016). Analisis regresi dalam penelitian ekonomi dan bisnis. PT. RajaGrafindo Persada. 
BPS Provinsi Jawa Timur. (2020). Provinsi Jawa Timur dalam angka 2020. Surabaya.

Croissant, Y., \& Millo, G. (2008). Panel data econometrics in R: The plm package. Journal of Statistical Software, 27(2), 1-42. doi: 10.18637/jss.v027.i02.

Gujarati, D. N. (2016). Dasar-dasar ekonometrika (Edisi Ketiga). Salemba Empat.

Hamzah, M. Z., Risqiani, R., \& Sofilda, E. (2012). Human development quality and its problems in Indonesia. OIDA International Journal of Sustainable Development, 5(7), 29-36. Retrieved from: https://papers.ssrn.com/sol3/ papers.cfm?abstract_id=2192206.

Hatta, R., \& Khoirudin, R. (2020). Analisis tingkat kemiskinan di Propinsi NTT: Pendekatan dua panel. Jurnal Samudra Ekonomi dan Bisnis, 11(2), 138-150. doi: 10.33059/jseb.v11i2.2004.

Heka, A. J. L. (2017). Pengaruh pengeluaran pemerintah bidang kesehatan dan pendidikan terhadap indeks pembangunan manusia di Provinsi Sulawesi Utara. EFISIENSI, 17(1), 206-217. Retrieved from: https://ejournal.unsrat. ac.id/index.php/jbie/article/view/16658.

Jasasila, J. (2020). Pengaruh tingkat kemiskinan dan jumlah penduduk terhadap indeks pembangunan manusia (IPM) Kabupaten Batanghari 20112019. Eksis: Jurnal Ilmiah Ekonomi dan Bisnis, 11(1), 40-44. doi: 10.33087/eksis.v11i1.192.

Kahang, M., Saleh, M., \& Suharto, R. B. (2016). Pengaruh pengeluaran pemerintah sektor pendidikan dan kesehatan terhadap indeks pembangunan manusia di Kabupaten Kutai Timur. Forum Ekonomi, 18(2), 130-140. doi: 10.29264/jfor.v18i2.863.

Marta, J., Fauzi, A., Juanda, B., \& Rustiadi, E. (2019). Migrasi desa-kota di Indonesia: Keputusan, pola dan perilaku serta konsekuensi. Retrieved from: https://202.124.205.241/handle/ $123456789 / 103346$.
Meydiasari, D. A., \& Soejoto, A. (2017). Analisis pengaruh distribusi pendapatan, tingkat pengangguran, dan pengeluaran pemerintah sektor pendidikan terhadap IPM di Indonesia. JPEKA: Jurnal Pendidikan Ekonomi, Manajemen dan Keuangan, 1(2), 116126. doi: 10.26740/jpeka.v1n2.p116126.

Muliza, M., Zulham, T., \& Seftarita, C. (2017). Analisis pengaruh belanja pendidikan, belanja kesehatan, tingkat kemiskinan dan PDRB terhadap IPM di Provinsi Aceh. Jurnal Perspektif Ekonomi Darussalam, 3(1), 51-69. doi: 10.24815/jped.v3i1.6993.

Nasution, L. N. (2019). Kajian tingkat kemiskinan di Kabupaten Batu Bara Provinsi Sumatera Utara pasca pemekaran. Ekonomikawan: Jurnal Ilmu Ekonomi dan Studi Pembangunan, 19(1), 13-20. doi: 10.30596/ekonomi kawan.v19i1.3235.

Ningrum, J. W., Khairunnisa, A. H., \& Huda, N. (2020). Pengaruh kemiskinan, tingkat pengangguran, pertumbuhan ekonomi dan pengeluaran pemerintah terhadap indeks pembangunan manusia (IPM) di Indonesia tahun 2014-2018 dalam perspektif Islam. Jurnal Ilmiah Ekonomi Islam (JIEI), 6(2), 212-222. doi: 10.29040/jiei.v6i2.1034.

Ningrum, S. S. (2017). Analisis pengaruh tingkat pengangguran terbuka, indeks pembangunan manusia, dan upah minimum terhadap jumlah penduduk miskin di Indonesia tahun 2011-2015. Jurnal Ekonomi Pembangunan, 15(2), 184-192. doi: 10.22219/jep.v15i2.5364.

Nisa, K., Wulandari, A., \& Rahayu, R. L. (2020). Pengaruh ketimpangan pendapatan terhadap kemiskinan di Provinsi Kepulauan Bangka Belitung tahun 2009-2018. SOROT, 15(1), 5563. doi: 10.31258/sorot.15.1.55-63.

Nugraha, D. P. (2020). Kemiskinan di Kota Bengkulu, apa penyebabnya? Jurnal Ilmu Ekonomi dan Pembangunan (JIEP), 20(1), 31-37. doi: 10.20961/ jiep.v20i1.35514. 
Palenewen, T. O. M., Walewangko, E. N., \& Sumual, J. I. (2018). Pengaruh pengeluaran pemerintah sektor pendidikan dan sektor kesehatan terhadap IPM dan dampaknya terhadap kemiskinan di Sulawesi Utara. Jurnal Berkala Ilmiah Efisiensi, 18(4), 52-61. Retrieved from: https://ejournal.unsrat.ac.id/index.php/j bie/article/view/20950.

Peraturan Pemerintah Republik Indonesia Nomor 78 Tahun 2015 tentang Pengupahan. Jakarta.

Sartika, C., Balaka, M. Y., \& Rumbia, W. A. (2016). Studi faktor-faktor penyebab kemiskinan masyarakat Desa Lohia Kecamatan Lohia Kabupaten Muna. Jurnal Ekonomi (JE), 1(1), 106-118. Retrived from: http://files/853/Sartika et al. - 2016 - Studi Faktor-Faktor Penyebab Kemiskinan Masyarakat.pdf.

Sinuraya, M. B. (2020). Pengaruh pengeluaran pemerintah, kemiskinan, pengangguran, dan pertumbuhan ekonomi terhadap IPM di Provinsi Sumatera Utara. JEpa, 5(2), 217-223. Retrieved from: http://jurnal.pancabudi. ac.id/index.php/jepa/article/view/909.

Sriyana, J. (2015). Metode regresi data panel. Ekonesia.
Sukirno, S. (2004). Makroekonomi teori pengantar (Edisi ketiga). PT. Raja Grafindo Persada.

Syofya, H. (2018). Pengaruh tingkat kemiskinan dan pertumbuhan ekonomi terhadap indeks pembangunan manusia Indonesia. Jurnal Ilmiah Ekonomi dan Bisnis, 15(2), 177-185. doi: 10.31849/ jieb.v15i2.1153.

Tarumingkeng, W. A., Rumate, V. A., \& Rotinsulu, T. O. (2018). Pengaruh belanja modal dan tingkat kemiskinan terhadap indeks pembangunan manusia (IPM) di Provinsi Sulawesi Utara. Jurnal Pembangunan Ekonomi dan Keuangan Daerah, 19(2), 82-95. doi: 10.35794/jpekd.32728.19.2.2018.

Umiyati, E., Amril, A., \& Zulfanetti, Z. (2017). Pengaruh belanja modal, pertumbuhan ekonomi dan jumlah penduduk miskin terhadap indeks pembangunan manusia di kabupaten/ kota Provinsi Jambi. Jurnal Sains Sosio Humaniora, 1(1), 29-37. doi: 10.22437/jssh.v1i1.3764.

Widarjono, A. (2013). Ekonometrika pengantar dan aplikasinya disertai panduan Eviews. UPP STIM YKPN. 